\section{Journal of Anatolian Environmental and Animal Sciences (Anadolu Çevre ve Hayvancılık Bilimleri Dergisi) \\ Doi: https://doi.org/10.35229/jaes.551720}

\title{
Acute Toxicity of Ammonium Sulfate Fertilizer to Bufo bufo Tadpoles from Turkey
}

\author{
Gülşah Bilaloğlu ${ }^{1} \quad$ Tuğba ERGÜL KALAYCI ${ }^{1} \quad$ Nurhayat ÖZDEMIIR $^{1 *}$ \\ ${ }^{1}$ Recep Tayyip Erdoğan University, Faculty of Arts and Sciences, Department of Biology, Rize, Turkey \\ (D): https://orcid.org/0000-0002-1906-6523, (D): https://orcid.org/0000-0002-4790-0263, * (D): https://orcid.org/0000-0002-3880-5846
}

\begin{abstract}
In this study, we determined acute toxicological effects of ammonium sulfate in Bufo bufo tadpoles. Hence, the animals were exposed (at Gosner stage 32) to six different concentrations of ammonium sulfate $(75,100,250,500,750 \mathrm{and} 1000 \mathrm{mg} / \mathrm{L}$ ) by $96 \mathrm{~h}$. Some morphological and behavioral abnormalities were detected at the end of the test. Irregular swimming, edema, scolosis, depigmentation were seen in tadpoles exposed to high concentrations of ammonium treatment. Dead tadpoles were existed only in 750 and $1000 \mathrm{mg} / \mathrm{L}$. There was no significant differences among treatments according to Kaplan-Meier survival test. Statistical differences were detected between control and treatment groups in terms of body length and weight. Although the results of this study indicated that only high ammonium concentrations had lethal effects on tadpoles, it must be born in mind that the developmental stage of the test animals should be considered when evaluating the risk of ammonium to amphibians.
\end{abstract}

Keywords: Acute toxicology, Ammonium sulfate, Behavioral changes, Bufo bufo, morphological changes.

\section{Amonyum sülfat gübresinin Türkiye'den Bufo bufo larvaları üzerindeki akut toksik etkileri}

Öz: Bu çalışmada, amonyum sülfatın Bufo bufo larvaları üzerindeki akut toksikolojik etkileri belirlenmiştir. Bu nedenle, hayvanlar (Gosner 32 aşamasında) 96 s. boyunca altı farklı amonyum sülfat konsantrasyonuna (75, 100, 250, 500, 750 ve 1000 mg / L) maruz bırakılmıştır. Test sonunda bazı morfolojik ve davranışsal anormallikler tespit edildi. Yüksek konsantrasyonlarda amonyum muamelesine maruz kalan larvalarda düzensiz yüzme, ödem, omurga eğriliği, depigmentasyon görüldü.Ölü larvalar sadece 750 ve 1000 mg/L'de mevcuttu. Kaplan-Meier sağkalım testine göre uygulamalar arasında anlamlı fark yoktu. Kontrol grubu ile uygulama grupları arasında vücut uzunluğu ve kilo bakımından istatistiksel farklar tespit edildi. Bu çalışmanın sonuçları, sadece yüksek amonyum konsantrasyonlarının larvalar üzerinde öldürücü etkilere sahip olduğunu göstermesine rağmen, amfibiler üzerinde amonyumun riskini değerlendirirken test hayvanlarının gelişim aşamasının dikkate alınması gerektiği unutulmamalıdır. 


\section{INTRODUCTION}

Tadpoles are useful biologic indicators for monitoring environmental pollutions (Cooke, 1981). They develop different morphological and physiological responses such as changes in development rates and growth, pigmentation and morphological disorders against to pollutions (Khangarot \& Ray, 1987). Also, it is a known fact that chemical contamination of freshwater systems is lead to amphibian populations to decline all over the world (Collins \& Storfer, 2003). Increased nitrogen concentrations in aquatic ecosystems, cause both direct and indirect effects on the biota. Most nitrogenous contaminants in nature results from fertilizers using in agriculture areas. Studies showed that amphibian mortality and possibly local population declines caused by nitrogen fertilizer applications in various locations around the world (Cooke, 1972; Berger, 1987, 1989; Hecnar, 1995; Marco et al., 1999; Rouse et al., 1999).

The common toad Bufo bufo (Linnaeus, 1758) is a species that lives in a wide variety of habitats including agricultural sites. This species is widespread in Europe (excluding Ireland and most Mediterranean islands), and northern Eurasia, with populations in parts of West Asia (Turkey, Syrian Arab Republic and Lebanon) and North Africa (Morocco, Algeria and Tunisia) (IUCN, 2019). Despite of being in the Least Concern (LC) IUCN category (2019), some populations of B. bufo has been locally decreased (Pavignano \& Giacoma, 1990; Carrier \& Beebee, 2003). Researchers reported that spawned ponds for this species generally come up against the spring fertilizer application (Xu \& Oldham, 1997) since they used water bodies in the spring time. IUCN Red List remarked that pollution and agricultural intensification are one of the its threats (IUCN, 2019). Although toxic effect of many contaminants on B. bufo species revealed in literature (Hecnar, 1995, Xu \& Oldham, 1997; Bernabó et al., 2008, Brunelli et al., 2009), no study has been existed about the effects of ammonium sulfate compound particularly. Since previous studies demonstrated that ammonium sulfate can be essentially attributed to the ions nitrate, nitrite and ammonium, respectively (Baker \& Waights, 1994; Schuytema \& Nebeker, 1999), it is crucial to reveal the effects of this compound on B. bufo. Despite this contaminant commonly using as a fertilizer in agricultural areas, there is no study revealed the toxic contaminant effects on $B$. bufo species from Turkey.

In this study, we aimed to determine the morphologically acute toxic effects of ammonium sulfate on the development, growth, and survival rates of $B$. bufo tadpoles from Çamlıhemşin, Rize, Turkey under the laboratory conditions.

\section{MATERIAL and METHOD}

Experimental Animals: Eggs of Common Toad (B. bufo) were collected from a pond in the Çat plateau (Çamlihemşin, Rize) (40.92804, 40.95411; 1300 a.s.1.) in the daytime May, 2014. The sampling was carried out with the permission of the local ethics committee for animal experiments (approval reference number: 2014/39). Then the eggs were moved to the Zoology laboratory of Recep Tayyip Erdoğan University and kept in aquariums at $21^{\circ} \mathrm{C}$. The experimental design of acute toxicity test performed according to Nikoloff et al., (2014) with modifications. Congruently, the larvae were fed with boiled lettuce and maintained daily until the tadpoles reached Gosner stage 32 (Gosner, 1960). They were not fed during the $96 \mathrm{~h}$ of toxicity test.

Water Quality: Water samples were taken during the field work and ammonium, nitrate and nitrite levels were measured using the Merck Spektroquant kit. Also $\mathrm{pH}$ and temperature values of water were measured in the field study. Water quality determined with the criteria given by Ministry of Forestry and Water Affairs of Turkey (Table 1).

Table 1. Inland water classification parameters according to the Ministry of Forestry and Water Affairs of Turkey.

\begin{tabular}{|c|c|c|c|c|}
\hline \multirow[b]{2}{*}{ Water classification parameters } & \multicolumn{4}{|c|}{ Water quality classes } \\
\hline & $\begin{array}{l}\text { I. Quality water (First } \\
\text { quality water) }\end{array}$ & $\begin{array}{l}\text { II. Quality water (Less } \\
\text { contaminated water) }\end{array}$ & $\begin{array}{c}\text { III. Quality water } \\
\text { (Contaminated water) }\end{array}$ & $\begin{array}{l}\text { IV. Quality water (High } \\
\text { contaminated water) }\end{array}$ \\
\hline Temperature $\left({ }^{\circ} \mathrm{C}\right)$ & 25 & 25 & 30 & $>30$ \\
\hline $\mathrm{pH}$ & $6.5-8.5$ & $6.5-8.5$ & $6.0-9.0$ & $>6.0-9.0$ \\
\hline Oxygen saturation (\%) & 90 & 70 & 40 & $<40$ \\
\hline Dissolved oxygen $\left(\mathrm{mg} \mathrm{O}_{2} / \mathrm{L}\right)$ & 8 & 6 & 3 & $<3$ \\
\hline Ione of sulfate $\left(\mathrm{mg} \mathrm{SO}_{4}{ }^{-2} / \mathrm{L}\right)$ & 200 & 200 & 400 & $>400$ \\
\hline Ammonium nitrogen $\left(\mathrm{mg} \mathrm{NH}{ }_{4}^{+}-\mathrm{N} / \mathrm{L}\right)$ & $0.2^{\mathrm{c}}$ & $1^{\mathrm{c}}$ & $2^{c}$ & $>2$ \\
\hline Nitrite nitrogen $\left(\mathrm{mg} \mathrm{NO}_{2}^{-}-\mathrm{N} / \mathrm{L}\right)$ & 0.002 & 0.01 & 0.05 & $>0.05$ \\
\hline Nitrate nitrogen $\left(\mathrm{mg} \mathrm{NO}_{3}-\mathrm{N} / \mathrm{L}\right)$ & 5 & 10 & 20 & $>20$ \\
\hline
\end{tabular}

Toxicity Bioassays: In this acute toxicology work, Ammonium sulfate, $\left(\mathrm{NH}_{4}\right)_{2} \mathrm{SO}_{4}$ (Sigma) were studied by dissolving we dissolved proper grade of solution in tap water. The chemical was added at the beginning of the test. For acute exposure, concentrations of $75,100,250,500,750$ and $1000 \mathrm{mg} / \mathrm{L}$ and a control group of ammonium sulfate were used in tests.

The exposure of acute test lasted 96 h. All tests, including control group were performed 5 times for each concentration. 5 tadpoles were used for each $5 \mathrm{~L}$ containers (total of 175 individuals were used in test). The temperature and oxygen of the water were evaluated every $24 \mathrm{~h}$. Dead individuals were counted and behavioral abnormalities such as swimming disorders, abnormal movements were noted every $12 \mathrm{~h}$ until the end of the tests.

Body size and weight were measured before and after the test. The mean values of the individual groups were taken into account for the present study.

Normality was calculated via Kolmogrov-Smirnov test (p-values less than 0.05 were considered statistically significant) and statistical differences between body length and weight changes between groups were analyzed by Kruskal-Wallis test. $\mathrm{LC}_{10}, \mathrm{LC}_{50}$ and $\mathrm{LC}_{70}$ values were determined using Probit analysis. After exposed the LC99 to different concentrations of ammonium sulfate, we analyzed the survival rates of tadpoles using with Kaplan-Meier 
survival and failure time analysis tests. All statistical tests were conducted with SPSS 21 .

\section{RESULTS}

Behavioral and morphological changes: The morphological and behavioral changes observed at different ammonium sulfate levels were the following:

Control group $(0 \mathrm{mg} / \mathrm{L})$ : there were no behavioral changes or no death were observed. Also, morphology of tadpoles were not changed.

$75 \mathrm{mg} / \mathrm{L}$ concentration: Tadpoles displayed similar behaviour as in normal in this concentration. But some of them suffered from bent tails (Figure 1A).

$100 \mathrm{mg} / \mathrm{L}$ concentration: There were no abnormal behavior (reduced swimming or feeding) throughout the experiment in this concentration. But morphological changes (like bent tails, edema and depigmentation) were seen (Figure 1B).

$250 \mathrm{mg} / \mathrm{L}$ concentration: Behavioral abnormalities were not seen, but small body malformation were seen in this concentration (Figure 1C).

$500 \mathrm{mg} / \mathrm{L}$ concentration: Activities were started to decrease at this concentration. Depigmentation, bent tail and edema were also detected in this group (Figure 1D).

$750 \mathrm{mg} / \mathrm{L}$ concentration: Irregular swimming and immobility were started at this point. In addition to that, edema, scolosis, depigmentation and some other malformation were increased in this concentration. A total of 2 individuals were dead in this concentration (Figure 1E).

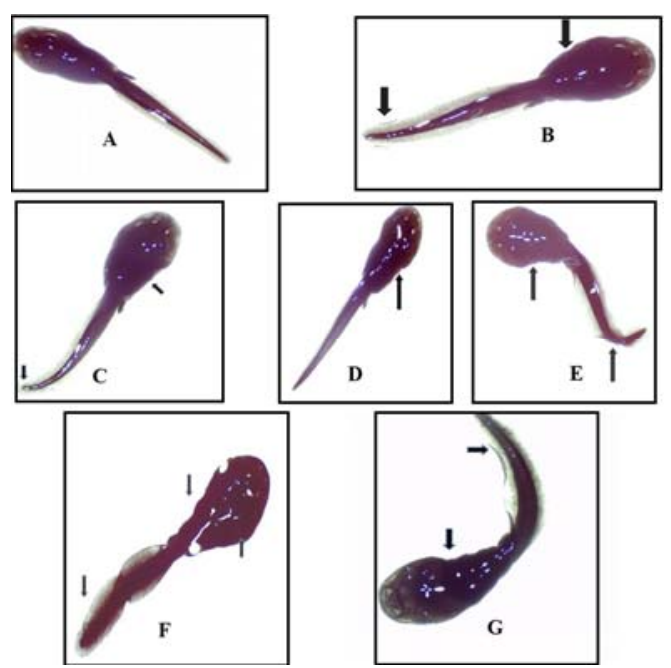

Figure 1. A) Control group B) Tadpole exposed to $75 \mathrm{mg} / \mathrm{L}$ (arrow showed bent tails and body malformation) C) Tadpoles exposed to $100 \mathrm{mg} / \mathrm{L}$ (arrow showed that edema and bent tails) D) Tadpoles exposed to $250 \mathrm{mg} / \mathrm{L}$ (arrow showed that articulation in the body) E) Tadpoles exposed to $500 \mathrm{mg} / \mathrm{L}$ (arrows showed that bent tails, edema and loss of pigmentation) F) Tadpoles exposed to $750 \mathrm{mg} / \mathrm{L}$ (arrows showed that malformation in tail and scoliosis) G) Tadpoles exposed to $1000 \mathrm{mg} / \mathrm{L}$ (arrows showed that malformation in the body and tail).

$1000 \mathrm{mg} / \mathrm{L}$ concentration: Initially tadpoles sank down to the bottom and became motionless. Edema, bent tail, pigmentation, decreased in body size and malformation in the trunk were seen in this concentration. 6 individuals were dead throughout the experiment at this concentration (Figure $1 \mathrm{~F})$.

There was no significant differences among treatments according to Kaplan-Meier survival test $(\chi 2=$ $10.8, \mathrm{p}>0.05)$ (Figure 2).

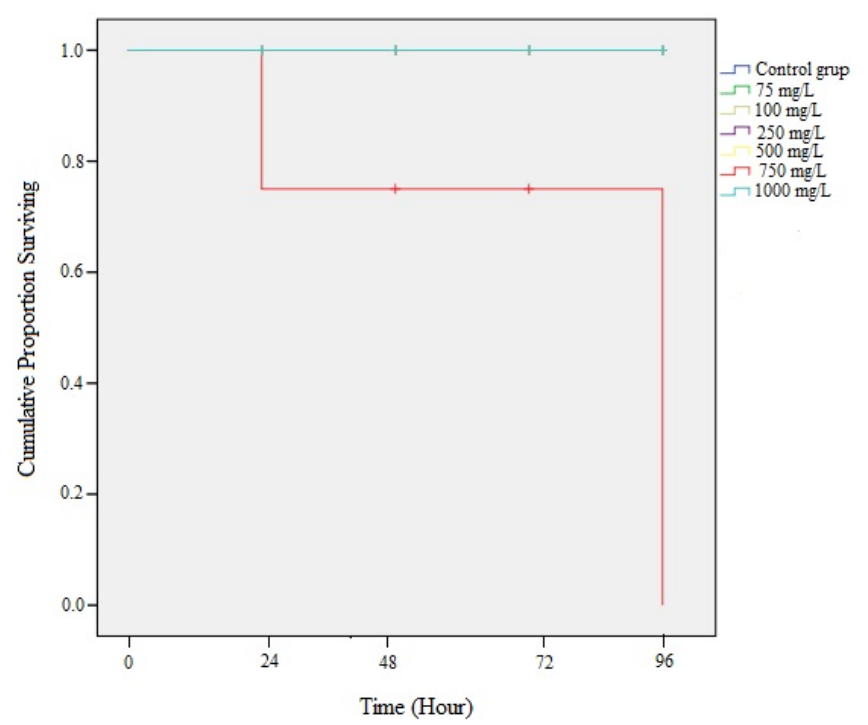

Figure 2. Cumulative survival (Kaplan-Meier) of $B$. bufo tadpoles after exposure to ammonium sulfate at different concentrations.

After the acute exposure LC values were detected as $868.750\left(\mathrm{LC}_{10}\right), 1155.672\left(\mathrm{LC}_{50}\right)$ and $1273.078\left(\mathrm{LC}_{70}\right) \mathrm{mg} / \mathrm{L}$ (Table 2).

Table 2. Lethal concentrations of ammonium sulfate exposure for B. bufo.

\begin{tabular}{cccc}
\hline Lethal & Concentrations & \multicolumn{2}{c}{$\% 95$ Confidence Interval } \\
\cline { 3 - 4 } concentrations & $(\mathrm{mg} / \mathrm{L})$ & Lower Bound & Upper Bound \\
\hline $\mathrm{LC}_{10}$ & 868.750 & 532.028 & 980.514 \\
$\mathrm{LC}_{50}$ & 1155.672 & 1025.271 & 2177.651 \\
$\mathrm{LC}_{70}$ & 1273.078 & 1099.162 & 2795.450 \\
$\mathrm{LC}_{99}$ & 1676.509 & 1331.624 & 4939.776 \\
\hline
\end{tabular}

Body size and weight alteration: Comparative values of measurements before and after exposure were given in Table 3. Body size and weight were significantly decreased at the highest concentrations. B. bufo tadpoles exposed to $500 \mathrm{mg} / \mathrm{L}$ showed a significantly smaller size according to the control group. Also, tadpoles exposed to $1000 \mathrm{mg} / \mathrm{L}$ showed a significantly smaller size according to $75 \mathrm{mg} / \mathrm{L}$ concentration $(\mathrm{p}<0.05)$. the tadpoles in highest concentration were significantly weaker than the control, 75 $\mathrm{mg} / \mathrm{L}, 100 \mathrm{mg} / \mathrm{L}$ and $250 \mathrm{mg} / \mathrm{L}$ concentration $(\mathrm{p}<0.05)$. Statistical differences were detected between control and treatment groups in terms of body length and weight (Kruskal Wallis, body length; $\chi 2=33.521, \mathrm{df}=6, \mathrm{p}<0.05$, weight; $\chi 2=$ 44.113, df $=6, \mathrm{p}<0.05)$.

Water Quality: Values gathering from $\mathrm{NO}_{2}, \mathrm{NO}_{3}$, $\mathrm{NH}_{4}, \mathrm{NH}_{4}-\mathrm{N}$ and $\mathrm{SO}_{4}$ determined as $0.010,2.2,0.10-0.03$, 0.071-0.025 and 1-2 mg/L (Table 4). Under the criteria of the Ministry of Forestry and Water Affairs, our water samples were classified as first quality water except for nitrite nitrogen parameter. This parameter classified as less contamined water. 
Table 3. Comparison of morphological measurements of before and after treatment.

\begin{tabular}{cccc}
\hline & & Before treatment & After treatment \\
\hline & Concentrations $(\mathrm{mg} / \mathrm{L})$ & Mean \pm S.D. & Mean \pm S.D. \\
\hline \multirow{4}{*}{ Body length } & 0 & $20.30 \pm 2.50$ & $0.39 \pm 0.01$ \\
& 75 & $20.38 \pm 1.17$ & $0.39 \pm 0.06$ \\
& 100 & $19.96 \pm 1.60$ & $0.39 \pm 0.01$ \\
& 250 & $19.38 \pm 1.15$ & $0.39 \pm 0.01$ \\
500 & $18.11 \pm 2.92$ & $0.39 \pm 0.03$ \\
& 750 & $21.34 \pm 1.10$ & $0.39 \pm 0.01$ \\
& 1000 & $21.49 \pm 1.14$ & $0.39 \pm 0.02$ \\
\hline \multirow{4}{*}{ Weight } & 0 & $20.30 \pm 2.50$ & $0.38 \pm 0.01$ \\
& 75 & $20.17 \pm 1.1$ & $0.35 \pm 0.07$ \\
& 100 & $18.72 \pm 1.6$ & $0.35 \pm 0.01$ \\
& 250 & $19.60 \pm 1.00$ & $0.34 \pm 0.01$ \\
& 500 & $18.84 \pm 1.50$ & $0.32 \pm 0.01$ \\
& 750 & $20.19 \pm 1.00$ & $0.25 \pm 0.01$ \\
& 1000 & $20.43 \pm 0.80$ & $0.23 \pm 0.09$ \\
\hline
\end{tabular}

Table 4. Water classification parameters and quality of waters of studied area.

\begin{tabular}{llll}
\hline Water classification parameters & Pond 1 & Pond 2 & Pond 3 \\
\hline Temperature $\left({ }^{\circ} \mathrm{C}\right)$ & 9.9 & 9.9 & 10.2 \\
$\mathrm{pH}$ & 8.76 & 8.76 & 8.76 \\
Oxygen saturation $(\%)$ & 91.6 & 90.8 & 94.9 \\
Dissolved oxygen $\left(\mathrm{mg} \mathrm{O}_{2} / \mathrm{L}\right)$ & 8.95 & 8.76 & 8.98 \\
Ione of sulfate $\left(\mathrm{mg} \mathrm{SO}_{4}^{-2} / \mathrm{L}\right)$ & 1 & 2 & - \\
Ammonium nitrogen $\left(\mathrm{mg} \mathrm{NH}_{4}{ }^{+}-\mathrm{N} / \mathrm{L}\right)$ & 0.071 & 0.141 & 0.025 \\
Nitrite nitrogen $\left(\mathrm{mg} \mathrm{NO}_{2}^{-}-\mathrm{N} / \mathrm{L}\right)$ & 0.01 & 0.01 & 0.01 \\
Nitrate nitrogen $\left(\mathrm{mg} \mathrm{NO}_{3}^{-}-\mathrm{N} / \mathrm{L}\right)$ & 2.2 & 2.2 & 2.2 \\
\hline
\end{tabular}

\section{DISCUSSION and CONCLUSION}

This first study evaluated the acute toxicities of ammonium sulfate to common frog (B. bufo) tadpoles from Turkey. As it is known, ammonium is the most toxic nitrogen to biota because of it is quickly oxidized to nitrate by bacteria and algae in the aquatic environment (Camargo \& Ward, 1992). Despite of this fact, $\mathrm{LC}_{50}$ value $(1155.672 \mathrm{mg} / \mathrm{L})$ was found very high in $B$. bufo. This variation in $\mathrm{LC}_{50}$ value could result from species differences in sensitivity or from differences in testing methodologies (Berrill et al., 1998, Bridges \& Semlitsch, 2000). LC $_{50}$ value of B. bufo tadpoles are very high and this situation indicated that ammonium sulfate were not very acutely toxic to $B$. bufo. In addition to that, the different sensitivities are also related to 1) tadpole size, 2) differences of life history traits and 3) the type of water normally inhabited by the tadpoles (Geng et al., 2005).

Wide range of toxic substance, including pesticide, herbicide, etc. were tested over the $B$. bufo species. Bernabó et al. (2008) investigated short-term toxicity of endosulfan which ranging from 0.01 to $0.6 \mathrm{mg} / \mathrm{L}$ in common toad tadpoles after 24,48 , and $96 \mathrm{~h}$ of exposure and stated that $0.43 \mathrm{mg} / \mathrm{L}$ of endosulfan caused $50 \%$ mortality $\left(\mathrm{LC}_{50}\right)$. Also, they found that morphological alterations occurred after $24 \mathrm{~h}$ and were more pronounced after 48 and $96 \mathrm{~h}$ of exposure.

With the exception of 750 and $1000 \mathrm{mg} / \mathrm{L}$ concentrations, no other treatment influenced larval life expectancy and little effects detected on growth of B. bufo, although other studies showed that ammonium may adversely affect amphibian growth. Exposure to ammonium (11.7 mg/L N-ammonium during ten days) also impaired growth in tadpoles of Xenopus laevis and Pseudacris regilla (Schuytema and Nebeker, 1999). Karaca et al., (2017) found that ammonium sulfate cause loss of life starting with low concentration. In our study was at very later stage (Goster stage 32) of its metamorphosis and body length and weight higher than other exposed organism in the literature. In the mean time, tadpoles which have a larger body size is stronger by showing resistance to the effects of chemicals (Geng et al., 2005).

Behavior was also weakly affected by exposure to ammonium sulfate. Reduced activity levels have already been observed in several amphibian species exposed to ammonium (Hecnar, 1995; Xu \& Oldham, 1997; Karaca et al., 2017). Although outcomes can be drived by environmental conditions in nature reduced activity levels negatively affect foraging, and consequently, larval growth (Skelly \& Werner, 1990; Relyea \& Werner, 1999) and competitive abilities (Semlitsch, 1993; Dayton \& Fitzgerald, 2001). Activities were stated to decrease in the high concentration of ammonium in B. bufo $(500 \mathrm{mg} / \mathrm{L})$ and abnormal swimming also showed in one of the highest concentration $(750 \mathrm{mg} / \mathrm{L})$. Baker and Waights (1993 \& 1994) found that concentrations of nitrate at 9 and $22.6 \mathrm{mg} / \mathrm{L}$ caused reduced growth, behavioral changes and increased mortality in the B. bufo and detected a large percentage of mortality within the first $96 \mathrm{~h}$.

Low dissolved oxygen levels (Allan et al., 1990) may increase the toxic effects of nitrate, nitrite and ammonia, also increasing temperature and especially $\mathrm{pH}$ increases the fraction of the highly toxic unionized ammonia relative to the moderately toxic ionized ammonium (Diamond et al., 1993; Hatch \& Blaustein, 2000). But none of these observed in this study. Because, temperature and oxygen saturation of studied area were detected very high. In addition to that ammonium nitrogen level of the ponds generally was very low (ranging 0.025 to $0.141 \mathrm{mg} \mathrm{NH}{ }^{+}-\mathrm{N} / \mathrm{L}$ ) in this study. Researchers showed that those given water measurements are appropriate for animal growth (Verep et al., 2017).

These results indicate that ammonium sulfate has relatively little developmental effects on $B$. bufo during the first $96 \mathrm{~h}$ of their life. Variation was detected among outcomes of toxic exposure of nitrogenous pollutant to $B$. bufo species. Researchers suggested that this could be due to differences in the test species and in experimental design (Rouse et al., 1999).

So the more ecotoxicological assessments from cultivated agricultural areas or even better urban areas is needed to more realistically characterize the ecological significance of toxic compound contamination in the environment.

\section{REFERENCES R}

Allan, G.L., Maguire, G.B. \& Hopkins, S.J. (1990). Acute and chronic toxicity of ammonia to juvenile Metapenaeus macleayi and Penaeus monodon and 
the influence of low dissolved-oxygen levels. Aquaculture, 91(3-4), 265-280.

Baker, J. \& Waights, V. (1993). The effect of sodium nitrate on the growth and survival of toad tadpoles (Bufo bufo) in the laboratory. Herpetological Journal, 3(4), 147-148.

Baker, J.M.R. \& Waights, V. (1994). The effects of nitrate on tadpoles of the tree frog (Litoria caerulea). Herpetological Journal, 4(3), 106-108.

Berger, L. (1987). Impact of agriculture intensification on Amphibia, In: van Gelder JJ, Strijbosh H, Bergers PJM (Ed), Proceedings of the Fourth Ordinary General Meeting of the Societas Europea Herpetologica, vol. 228, 65-73p, Nijmegen, Netherlands.

Berger, L. (1989). Disappearance of amphibian larvae in the agricultural landscape. Ecology International Bulletin, 17, 65-73.

Bernabò, I., Brunelli, E., Berg, C., Bonacci, A. \& Tripepi, S. (2008). Endosulfan acute toxicity in Bufo bufo gills: ultrastructural changes and nitric oxide synthase localization. Aquatic toxicology, 86(3), 447-456.

Bridges, C.M. \& Semlitsch, R.D. (2000). Variation in pesticide tolerance of tadpoles among and within species of Ranidae and patterns of amphibian decline. Conservation Biology, 14(5), 1490-1499.

Brunelli, E., Bernabò, I., Berg, C., Lundstedt-Enkel, K., Bonacci, A. \& Tripepi, S. (2009). Environmentally relevant concentrations of endosulfan impair development, metamorphosis and behaviour in Bufo bufo tadpoles. Aquatic Toxicology, 91(2), 135-142.

Camargo, J.A. \& Ward, J.V. (1992). Short-term toxicity of sodium nitrate $(\mathrm{NaNO} 3)$ to non-target freshwater invertebrates. Chemosphere, 24(1), 23-28.

Carrier, J.A. \& Beebee, T.J. (2003). Recent, substantial, and unexplained declines of the common toad Bufo bufo in lowland England. Biological Conservation, 111(3), 395-399.

Cooke, A.S. (1972). Indications of recent changes in status in the British Isles of the frog (Rana temporaraia) and the toad (Bufo bufo). Journal of Zoology, 167(2), 161-178.

Cooke, A.S. (1981). Tadpoles as indicators of harmful levels of pollution in the field. Environmental Pollution Series A, Ecological and Biological, 25(2), 123-133.

Dayton, G.H. \& Fitzgerald, L.A. (2001). Competition, predation, and the distributions of four desert anurans. Oecologia, 129(3), 430-435.

Diamond, J.M., MacKler, D.G., Rasnake, W. J. \& Gruber, D. (1993). Derivation of site-specific ammonia criteria for an effluent-dominated headwater stream. Environmental Toxicology and Chemistry, 12(4), 649-658.
Geng, B.R., Yao, D. \& Xue, Q.Q. (2005). Acute toxicity of the pesticide dichlorvos and the herbicide butachlor to tadpoles of four anuran species. Bulletin of environmental contamination and toxicology, 75(2), 343-349.

Gosner, K.L. (1960). A simplified table for staging anuran embryos and larvae with notes on identification. Herpetologica, 16(3), 183-190.

Hatch, A.C. \& Blaustein, A.R. (2000). Combined effects of UV-B, nitrate, and low $\mathrm{pH}$ reduce the survival and activity level of larval Cascades frogs (Rana cascadae). Archives of Environmental Contamination and Toxicology, 39(4), 494-499.

Hecnar, S.J. (1995). Acute and chronic toxicity of ammonium nitrate fertilizer to amphibians from southern Ontario. Environmental toxicology and chemistry, 14(12), 2131-2137.

Karaoğlu, H. (2011). Amonyum nitrat suni gübresinin Kafkas Kurbağası (Pelodytes caucasicus) larvalart üzerindeki akut ve kronik etkileri. Karadeniz Teknik Üniversitesi Fen Bil. Enst. Trabzon, Türkiye, 153s.

Karaca B., Özdemir, N. \& Ergül Kalayci, T. (2017). Some Toxic Effects of Ammonium Sulfate Fertilizer to Rana macrocnemis Tadpoles From Rize (Black Sea Region), Turkey. Biological Diversity and Conservation, 3, 101-107.

Khangarot, B.S. \& Ray, P.K. (1987). Sensitivity of toad tadpoles, Bufo melanostictus (Schneider), to heavy metals. Bulletin of environmental contamination and toxicology, 38(3), 523-527.

Marco, A. \& Blaustein, A.R. (1999). The effects of nitrite on behavior and metamorphosis in Cascades frogs (Rana cascadae). Environmental Toxicology and Chemistry, 18(5), 946-949.

Nikoloff, N., Natale, G.S., Marino, D., Soloneski, S. \& Larramendy, M.L. (2014). Flurochloridone-based herbicides induced genotoxicity effects on Rhinella arenarum tadpoles (Anura: Bufonidae). Ecotoxicology and Environmental Safety, 100, 275281.

Pavignano, I. \& Giacoma, C. (1990). Una valutazione ecologica dello stato di conservazione delle zone umide minori della pianura Piemontese-Atti VI Conv. naz. Ass.“A. Chigi”, Torino (1989). Museo Regionale di Scienze Naturali Torino, 91-104.

Relyea, R.A. \& Werner, E.E. (1999). Quantifying the relation between predator-induced behavior and growth per- formance in larval anurans. Ecology, 80, 2117-2124.

Rouse, J.D., Bishop, C.A. \& Struger, J. (1999). Nitrogen pollution: an assessment of its threat to amphibian survival. Environmental health perspectives, 107(10), 799-803.

Schuytema, G.S. \& Nebeker, A.V. (1999). Comparative toxicity of ammonium and nitrate compounds to 
Pacific treefrog and African clawed frog tadpoles. Environmental toxicology and chemistry, 18(10), 2251-2257.

Semlitsch, R.D. (1993). Asymmetric Competition In Mixed Populations of Tadpoles of The Hybridogenetic: Rana esculenta Complex. Evolution, 47(2), 510-519.

Skelly, D.K. \& Werner, E.E. (1990). Behavioral and life-historical responses of larval American toads to an odonate predator. Ecology, 71(6), 2313-2322.

Verep, B., Mutlu, T., Çakır, V. \& Aydın, G. (2017). Derepazarı Deresinin (Rize-TÜRKIYYE) FizikoKimyasal Su Kalitesinin Belirlenmesi ve Bazı Su Kalite Standartlarına Göre Değerlendirilmesi. Journal of Anatolian Environmental \& Animal Sciences, 2(1), 19-22
Xu, Q. \& Oldham, R.S. (1997). Lethal and sublethal effects of nitrogen fertilizer ammonium nitrate on common toad (Bufo bufo) tadpoles. Archives of Environmental Contamination and Toxicology, 32(3), 298-303.

\section{*Corresponding author's:}

Prof. Dr. Nurhayat ÖZDEMIR

Recep Tayyip Erdoğan University, Faculty of Arts and Sciences, Department of Biology, Rize, Turkey

E-mail: nurhayat.ozdemir@erdogan.edu.tr

ORCID: https://orcid.org/0000-0002-3880-5846 